\title{
Kultur för alla? Stockholmsoperan under 1800-talet
}

\section{Karin Hallgren}

I min forskning har jag framför allt ägnat mig åt studier av musikliv och repertoar under 1800-talet. Eftersom jag ägnat mig åt konstmusik har musiklivet i Stockholm och inte minst Stockholmsoperan varit en viktig del i min forskning. I dagens installationsföreläsning är det just institutionen Stockholmsoperan som står i fokus.

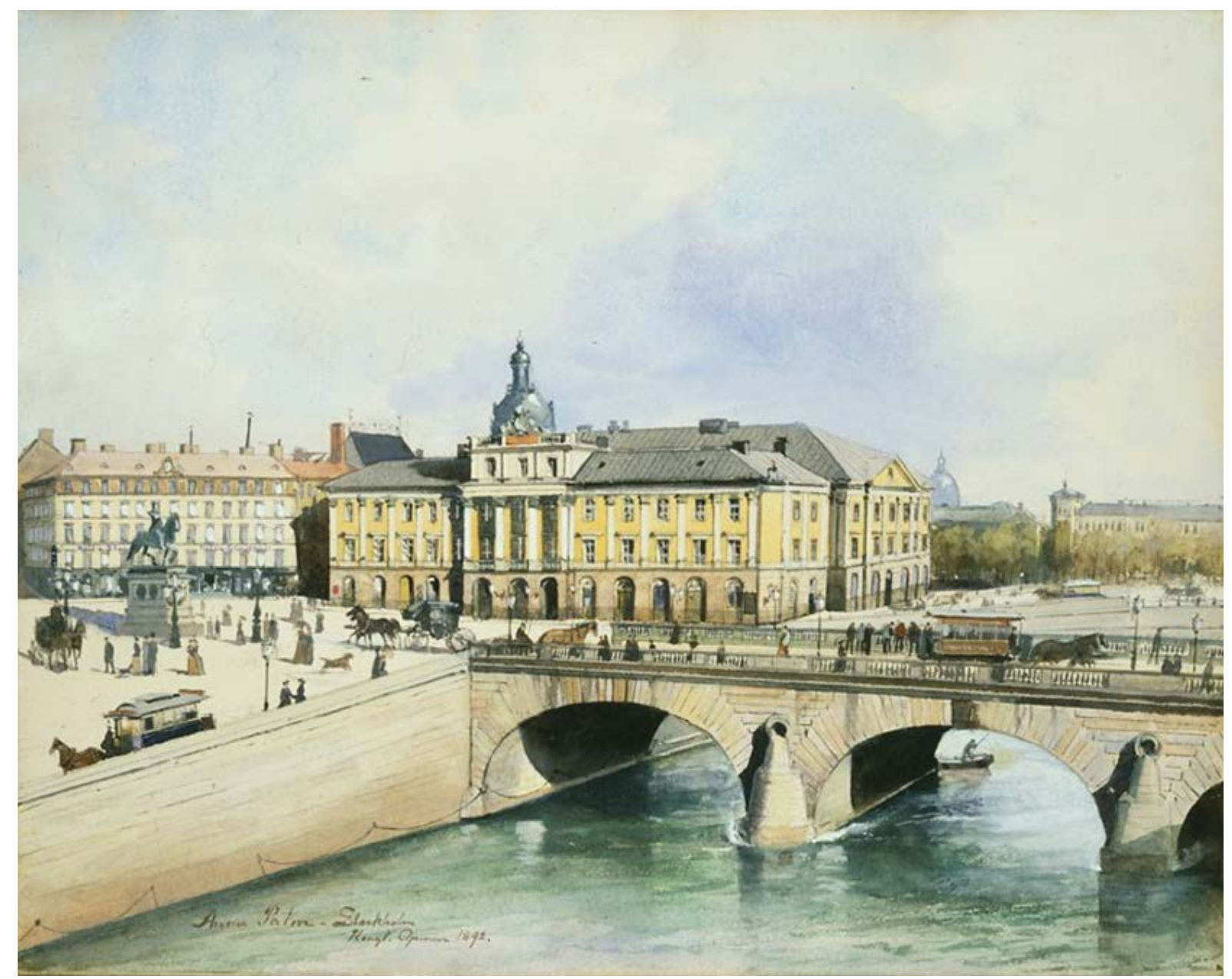

Bild 1. Målning från 1892 av Anna Palm (1859-1924) från Stockholms stadsmuseum, tillgänglig på www.stockholmskallan.stockholm.se. 
Det här är det som brukar kallas för det gustavianska operahuset, eftersom det var Gustav III som lät bygga det. Det stod färdigt 1782 och för första gången hade man nu en institution i Stockholm med en permanent ensemble för opera. Tidigare hade hoven engagerat resande opera-och teatersällskap, men en fast institution innebar utbildade musiker och sångare som ständigt skulle finnas på plats, vilket också ökade möjligheten att bygga upp en repertoar. Operan får därigenom en central roll för utvecklingen av konstmusiklivet i Sverige, det är därför den är intressant att studera. Och även om den är i Stockholm finns det beröringspunkter både med andra städer i landet och internationellt, inte minst för att både repertoar och artister ständigt rör sig mellan olika städer och länder.

Vad är då det här för någon sorts lokal? Förutom att den innehåller en scen och en salong är det också en arbetsplats för ett par hundra personer, som behövs för att det ska kunna bli några föreställningar. Den är också bostad för några, operachefen bor i en fin våning en trappa upp till exempel och även ett par andra personer har lägenheter här. Men Operan är också en debattarena för samhällsfrågor. Många verk anknyter på olika sätt till samhällsdebatten och Operan deltar på så sätt i konstruktionen av ideologiska ställningstaganden. Och sist, men inte minst, är förstås Operan en plats för fantasi och fantastiska upplevelser.

Just det faktum att Operan står stadigt förankrad i materiella förhållanden, samtidigt som den är en arena för fantasi och estetiska upplevelser är en dubbelhet som fascinerar mig. I den här föreläsningen vill jag, utifrån några olika verk, ge exempel på hur kulturinstitutionen Stockholmsoperan förändras under 1800-talets lopp, från att vara en kunglig hovopera till att bli en opera i ett offentligt musikliv. Frågan om man kan säga att operan blivit "kultur för alla” ska också kortfattat beröras.

Vid sin start är Operan en hovopera, det vill säga kungen bekostar hela verksamheten och han har också rätten att besluta över den i sin helhet. Det nya operahusets salong har omkring 900 platser. Publiken består av personer ur olika samhällsklasser, prydligt placerade i olika delar av salongen så man inte behöver riskera att stöta ihop med någon som tillhör en annan klass. Mest är det nog ändå högre borgerlighet och uppåt, och förstås medlemmar ur hovet, som finns i publiken.

Man kan undra vad Gustav III ville med sin opera, förutom då att få chans att utveckla sitt stora intresse för opera och teater. En av avsikterna var att kungen ville skapa svensk kultur som anknöt till den internationella traditionen. Kanske tyckte han det var lättare att göra det med musikens hjälp. Musikaliska akademien, med uppgift att få igång en opera, instiftades redan 1771, medan institutionen för talteatern (den som vi i dagligt tal nuförtiden kallar ”Dramaten”) inrättades först 1788.

Det första exemplet på ett operaverk från den här tiden är hämtat från 1786, det är premiäråret för operan Gustaf Wasa, med musik av den tyske tonsättaren Johann Gottlieb Naumann och text av Gustav III själv i samarbete med poeten Johan Henric Kellgren.

Operan blev mycket populär redan från den första säsongen den gavs. Den uppfattades ganska snart som en svensk "nationalopera”. Den handlar om Gustaf Vasas strider och äventyr, men uppfattades nog inte bara som en historisk skildring av publiken, utan också som händelser med samtida referenser. Exempelvis gick striderna i operan mellan danskar och svenskar att koppla till det rådande politiska läget, där det också fanns en konflikt mellan Sverige och Danmark. Det finns samtida skildringar av hur publiken levde sig med i 
händelseförloppet och livligt hejade på den svenska sidan med anspelningar på aktuella händelser.

I operan sjungs bland annat sången ”Ädla skuggor, vördade fäder”, där adelsmännen hyllar Gustav Vasa och betygar sin vördnad för traditionen. Den var lika giltig för den samtida situationen mellan kung Gustav III och hans adelsmän. (Lyssna på sången via denna Spotify-länk: https://open.spotify.com/track/41mr3FpgBYdp0QLLgHgu0e?si=hMcvTEFM T3eBb94dftmpSQ) Att skriva en opera om en svensk kung och koppla den till samtida händelser blir ett exempel på hur det som skildras från operascenen är med och konstruerar uppfattningen om det samtidas relation till historien.

Operahuset i Stockholm kan också ses som en brottsplats. För det var faktiskt här som Gustav III sköts på en maskeradbal 1792 och avled av skadorna någon tid senare. Efterträdaren, sonen Gustav IV Adolf, var av olika skäl inte intresserad av att hålla Operan igång. Han drog ner på verksamheten genom att avskeda flertalet musiker och sångare. De som var kvar fick uppträda på Arsenalsteatern. Det var en scen som användes för talteater och som låg i en byggnad alldeles bakom Operahuset vid Kungsträdgården. Det stora operahuset stängdes 1805. 1800-talets första decennium var händelserikt ur ett politiskt perspektiv. 1809 störtades Gustav IV Adolf i en statskupp. Påföljande år fick Sverige en ny kronprins, Jean Baptiste Bernadotte. När han kom till Stockholm på hösten 1810 firades det bland annat på Operan med en uppsättning av Gustaf Wasa. Det var en viktig symbolhandling att det stora operahuset kunde öppnas igen och att just Gustaf Wasa blev framförd. Som brukligt var gjorde man en direkt koppling mellan scenen i operan, där adelsmännen bedyrar sin trohet till kungen i sången ”Ädla skuggor”, till salongen där de besökande adelsmännen kunde betyga sin trohet till den nyvalde kronprinsen. Föreställningarna av Gustaf Wasa var i stort sett bara tillgängliga för en inbjuden publik. Kopplingen till viktiga händelser inom kungahuset och dess betydelse för monarkin är tydlig.

Medan Gustaf Wasa är en stort upplagd opera, med många solister, kör och brett anlagda scener, är nästa exempel något helt annat. Sångspelet Föreningen hade premiär i januari 1815 och spelades sammanlagt under sex säsonger (1815-1820), från 1817 alltid med start 4 november. Ett sångspel har talad dialog och många sånginslag, ofta i en visartad stil. Enkelheten i sångerna och ämnesvalet (mer om det nedan) visar att man med det här sångspelet vände sig till en bredare publik. Det visade sig också fungera, Föreningen framfördes ett stort antal föreställningar varje säsong, eftersom den lockade många besökare. Operaledningen var väldigt känslig för publiktillströmningen. Om en föreställning inte lockade en tillräckligt stor publik lades den ner direkt.

Handlingen i sångspelet kan kortfattat beskrivas på följande sätt: Historien utspelar sig i gränslandet mellan Sverige och Norge. Det bor en familj på varje sida om gränsen och det finns en ung man och en ung flicka i varje familj. De blir förälskade i varandra, den norska pojken i den svenska flickan och den norska flickan i den svenska pojken. Efter några mindre förvecklingar får de varandra och det blir stora bröllopsfestligheter på scenen. Festligheterna tar formen av ett divertissement, alltså en lång rad av sånger och danser som följer på varandra utan något tal emellan. Det var en mycket populär form vid den här tiden.

Divertissementet blir en provkarta på personer från olika delar av landet. De framträder och visar sin vördnad för kungen. Musiken är också hämtad från olika landsdelar. Sista kören med alla medverkande har texten ”Ett land, ett folk, en kung”, som upprepas ett antal gånger. 
Det var kronprinsen, Karl Johan, som själv beställt detta verk. Han ville ha en föreställning som klargjorde den officiella inställningen till den nyligen ingångna unionen med Norge, eftersom det fanns mycket opposition mot denna union. Även om kronprinsen själv inte var särskilt musikintresserad insåg han operans betydelse för opinionsbildningen. Från scenen var det möjligt att sprida en politisk uppfattning. Att ge föreställningarna med start 4 november, det vill säga på själva unionsdagen, var också en del i detta.

Från och med 1810 fick Operan ett mindre ekonomiskt bidrag från staten, samtidigt som kungen fortsatte att ge sitt ekonomiska bidrag. Biljettintäkterna stod dock fortfarande för den absolut största delen av inkomsterna. Verksamheten vid Operan vände sig nu till en något bredare publik än tidigare, samtidigt som man hade kvar karaktären av hovopera vid vissa tillfällen. Den här blandningen är typisk för Operans förutsättningar under 1800-talets första decennier. Man behövde alla sorters publik för att ha ekonomiska förutsättningar för att genomföra föreställningarna.

Under 1820- och 30-talen fortsätter operan sin verksamhet, med upp- och nergångar som det brukar vara. Vi gör ett hopp fram till 1840-talet. Då har vår stora operastjärna Jenny Lind sin verksamhetstid. Jenny Lind debuterade 1838 och deltog i ett stort antal föreställningar på Stockholmsoperan till 1842. Därefter hade hon en relativt kort men mycket framgångsrik internationell operakarriär till och med 1849. 


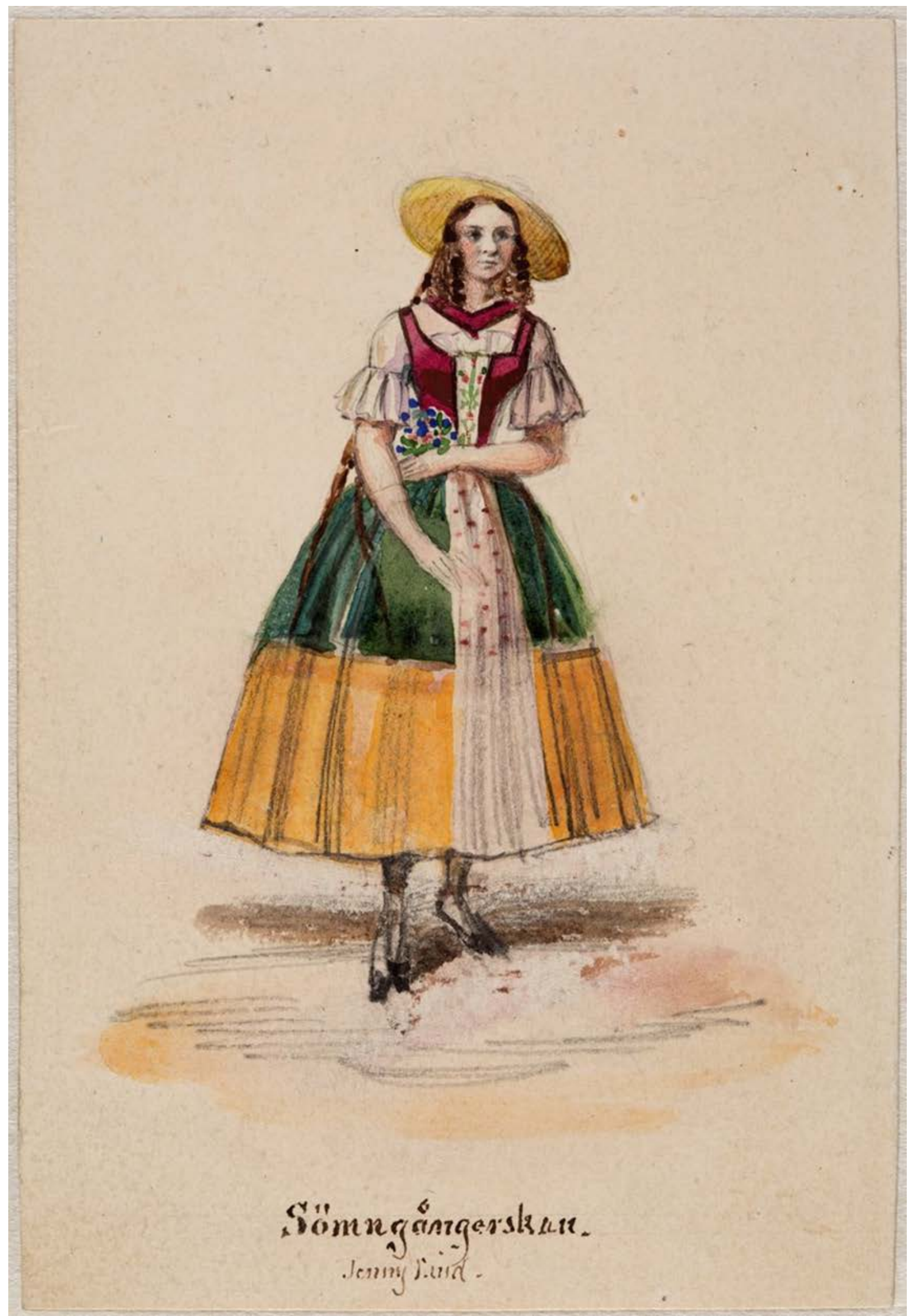

Bild 2. Målning av Joseph Wilhelm Wallander, förmodligen från 1843, från Stockholms stadsmuseum, tillgänglig på www.stockholmskallan.stockholm.se. 
En av rollerna ser vi på bilden, Amina i Sömngångerskan. Först en kort handlingsresumé : Handlingen utspelar sig i en liten by i schweiziska alperna. I byn finns ett slott, men greven som ägde slottet är nu död och hans son är försvunnen sedan länge. Den föräldralösa Amina har just förlovat sig med Elvino. Vid förlovningsfesten kommer en okänd ung man, han intresserar sig så mycket för Amina att Elvino blir svartsjuk. Den okände mannen känns senare igen som grevens son Rodolfo. Amina går i sömnen och går till Rodolfos rum där hon senare hittas sovande av byfolket. Elvino blir mycket upprörd och svartsjuk och han slår upp förlovningen. Inga bedyranden från Rodolfo och det övriga byfolket om Aminas oskuldsfullhet hjälper. När allt är som mest förvirrat öppnas dörren till Rodolfos rum och ut kommer Amina, som omigen går i sömnen. Hon tar vägen över en bro vid kvarnen. Man kan inte riskera att väcka henne, för då kan hon ramla och slå ihjäl sig. Istället väntar man medan hon lyckligt kommer över bron, fram till den väntande Elvino. Alla missförstånd klaras snabbt upp och de båda kan gifta sig. (Lyssna på arian som Amina sjunger när hon går över bron via denna Spotify-länk: https://open.spotify.com/track/3pnz6iH26OTEYGjIXmeiVv?si= l15iVewHShOhuiXAtIgpcQ)

Det finns en utbredd uppfattning att handlingen i operor alltid är fånig och den här operan kan man tycka bidrar till en sådan uppfattning. Den fick också kritik i samtiden för att den var tråkig, men ända hade den alltså fina sångpartier som inte minst Jenny Lind gjorde stor succé med. Och vi kan i efterhand mycket väl tolka handlingen till exempel ur genusperspektiv. Här finns tydliga uppfattningar om hur äktenskapet ska fungera och hur den ideala kvinnan ska uppföra sig.

Operan i Stockholm gav många föreställningar av Sömngångerskan, med Jenny Lind i rollen som Amina. Under 1840-talet sker det en breddning av publiken jämfört med tidigare, efterhand får man därför också möjlighet att ge fler föreställningar. En stjärna som Jenny Lind hade stor betydelse för det ökande operaintresset i Stockholm på 1840-talet. Musiken från operorna arrangerades också för piano och spreds i notalbum till framför allt borgerliga familjer, där möjligheten att spela och sjunga hemma var viktig. Även den som inte besökte operan kunde därför få del av den populära musiken, genom att den spreds via noter till hemmen.

Förutom åhörarnas förtjusning i Jenny Linds framföranden hade hon också stor betydelse för operans ekonomi. Ett gästspel som hon genomförde på Stockholmsoperan 1848 är bra exempel på detta. 


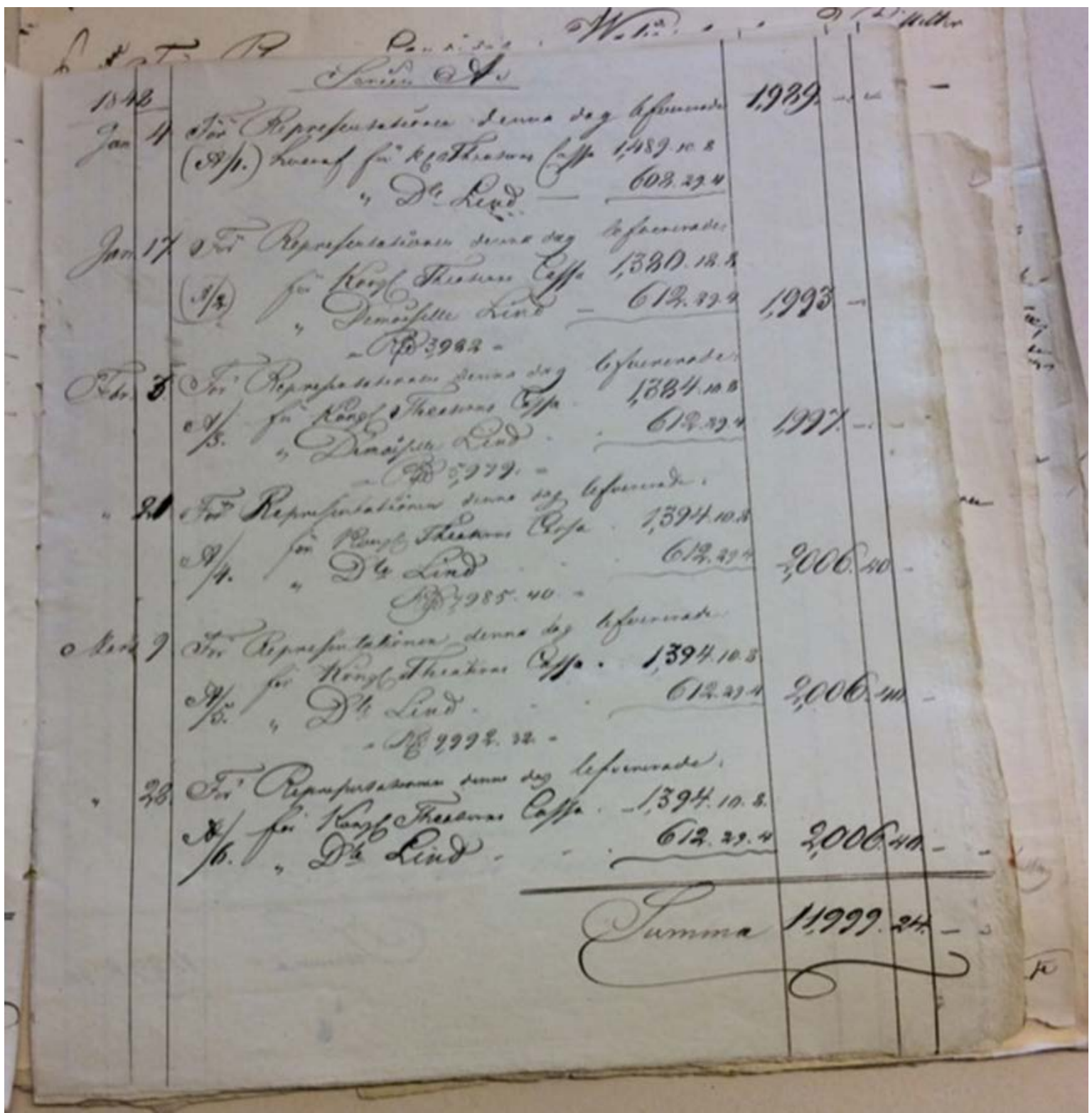

Bild 3. Stockholm: Kungl. Teatrarnas Arkiv, F4J Abonnemangshandlingar Volym 1, 1847/48. Av uppställningen framgår inkomsten från respektive föreställningen samt Jenny Linds andel.

Vid gästspelet, som ägde rum under perioden januari - mars, spelade Lind i tre olika operor (Sömngångerskan, Figaros bröllop, Lucia di Lammermoor), åtta föreställningar av varje. Arkivmaterial visar det stora intresset för att köpa biljetter till föreställningarna, där efterfrågan på biljetter översteg tillgången. Att det var en stor händelse med Jenny Linds gästspel framgår bland annat av att fördelningen av biljetter också meddelades i pressen.

Föreställningarna blev snabbt utsålda, trots att de gavs till förhöjt biljettpris. Arkivmaterial visar att varje föreställning inbringade ca 2000 riksdaler banko, varav 600 gick direkt till Jenny Lind. Om man jämför den köpkraft man fick 1848 av 600 riksdaler banko med dagens penningvärde, skulle den idag uppgå till 70000 svenska kronor. Det rörde sig alltså om stora pengar vid detta gästspel.

Man får av detta dra slutsatsen att vid mitten av 1800-talet är Operan i Stockholm en blandning mellan en traditionell hovopera och en opera för en borgerlig publik. Fortfarande 
används Operan för viktiga tilldragelser vid hovet, men föreställningar som ges på marknadens villkor blir allt vanligare från mitten av 1800-talet och framåt. Kommer det en stor stjärna kan man sälja biljetter till dubbla priset till exempel och man ser till att få ut så mycket det går också rent ekonomiskt av gästspelet.

Betydelsen av en borgerlig, betalande publik och av att Operan ger en repertoar som lockar denna publik, blir allt tydligare under andra hälften av 1800-talet. Intresset för grand opéra visar detta. Grand opéra är en genre som har sitt urprung i den franska operan, med Paris som ett självklart centrum vid 1800-talets mitt. Det är, som namnet antyder, stort upplagda verk i många akter, framförda av stor orkester, stor kör, balett och många sångsolister. Genren blir mycket populär och sprids runt om i Europa. Verken tilltalar en växande borgerlig publik. Från ca 1830 till ca 1890 finns det så gott som varje säsong minst en grand opéra på repertoaren i Stockholm. Ofta är det verk av Giacomo Meyerbeer, som var en av grand opéras främsta företrädare. Under perioden 1850-1875, då intresset för genren var som allra störst i Stockholm, gavs många föreställningar varje säsong. Publiken kom i stort antal trots att operorna alltid gavs till "förhöjt biljettpris", eftersom det var mycket kostsamt att sätta upp den här typen av opera. En av operorna är Hugenotterna av Meyerbeer. Den handlar om hur hugenotter (en grupp protestanter) blir nedslagna av katoliker i Paris 1572. Den är ett bra exempel på hur man använde historiska ämnen för att delta i den aktuella diskussionen om samhällsfrågor och samtidigt undvika censuren. Här kan man tänka sig att intresset hos publiken framför allt handlar om att man stödjer minoriteten (alltså hugenotterna) som sätter sig upp mot den konservativa överheten.I gestaltningen av händelserna gör man som brukligt är i grand opéra och låter individer gestalta konflikten: Dottern till en katolsk greve, Valerie, ska gifta sig med en protestantisk ädling, Raoul, för att underlätta kontakten mellan katoliker och protestanter. Men Raoul har felaktigt fått för sig att Valerie varit älskarinna åt en katolsk adelsman och vägrar giftermål under uppseendeväckande former. Katolikerna anser att denna skymf måste hämnas och de förbereder en attack. Valerie, som inte har något annat val än att gifta sig med katoliken Nevers, har fortfarande starka känslor för Raoul. Hon avslöjar därför katolikernas anfallsplaner för honom och de övriga hugenotterna. När striden genomförs är hugenotterna därför beredda och kan slå tillbaka. I striderna dör Valeries man, Nevers. Något senare ber Valerie Raoul att han ska gå över till katolikerna, för att rädda sitt liv, men han vägrar. Deras konflikt i denna fråga slutar istället med att Valerie går över till hugenotterna. I slutakten skildras katolikernas anfall på hugenotterna, där många dör och tre hugenotter tillfångatas. Vi i publiken vet att de tre är Valerie och hennes vänner, men katolikerna på scenen vet det förstås inte. På order från den katolske ledaren skjuts de tre hugenotterna. I den allra sista scenen uppdagas det att en av de skjutna är Valerie och att den som gett ordern är hennes far.

Handlingen, som är centrerad kring en mycket laddad konflikt, är typisk för grand opéra. Även här kan man analysera operans handling ur ett samtida perspektiv, där framför allt relationen mellan olika intressen i samhället står i fokus, samtidigt som skildringen av rollpersonernas öden gestaltas på ett gripande sätt.

I det klingande exemplet hör vi först de tre protestanterna, därefter kören med katoliker och sedan protestanterna igen. Psalmen "Vår gud är oss en väldig borg” används för att skildra protestanterna. (Lyssna via denna Spotifylänk: https://open.spotify.com/track/2mJP1F yRdoFMG8kCXbHa8T?si=HbDzT7AVRu2IpYKujV6dyg) 
Meyerbeers operor är ett steg till mot en operainstitution på den kommersiella marknaden. Operaledningen vill sätta upp verk som kan locka en stor publik många gånger till Operan. Kungahusets relation till Operan har samtidigt försvagats och föreställningar med direkt koppling till kungahuset är få. Fortfarande är Operan dock beroende av anslag från både staten och kungen.

Debatten om ekonomin och repertoaren intensifieras från 1860-talet och man diskuterar nu också vem som ska äga Operan. Ska den förbli en hovinstitution eller ska den överföras till något statligt departement? Det hus som invigts med stor uppmärksamhet och stolthet 1782 var nu, drygt 100 år senare, omodernt och dessutom utdömt av brandmyndigheterna. Vid 1880-talets början ställdes allt oftare frågan ”Vem vill äga det här operahuset?” Kungen ville inte längre i alla fall. 1881 förklarade Oscar II att han inte ville skjuta till mer pengar och Operan överfördes från hovförvaltningen och blev en statlig teater. Men svårigheterna för staten att driva Operan var stora, och den så kallade ”teaterfrågan” debatterades hela 1880talet utan att man kom till någon lösning.

Man måste till slut i alla fall göra något åt det hela. Och detta var vad som hände:

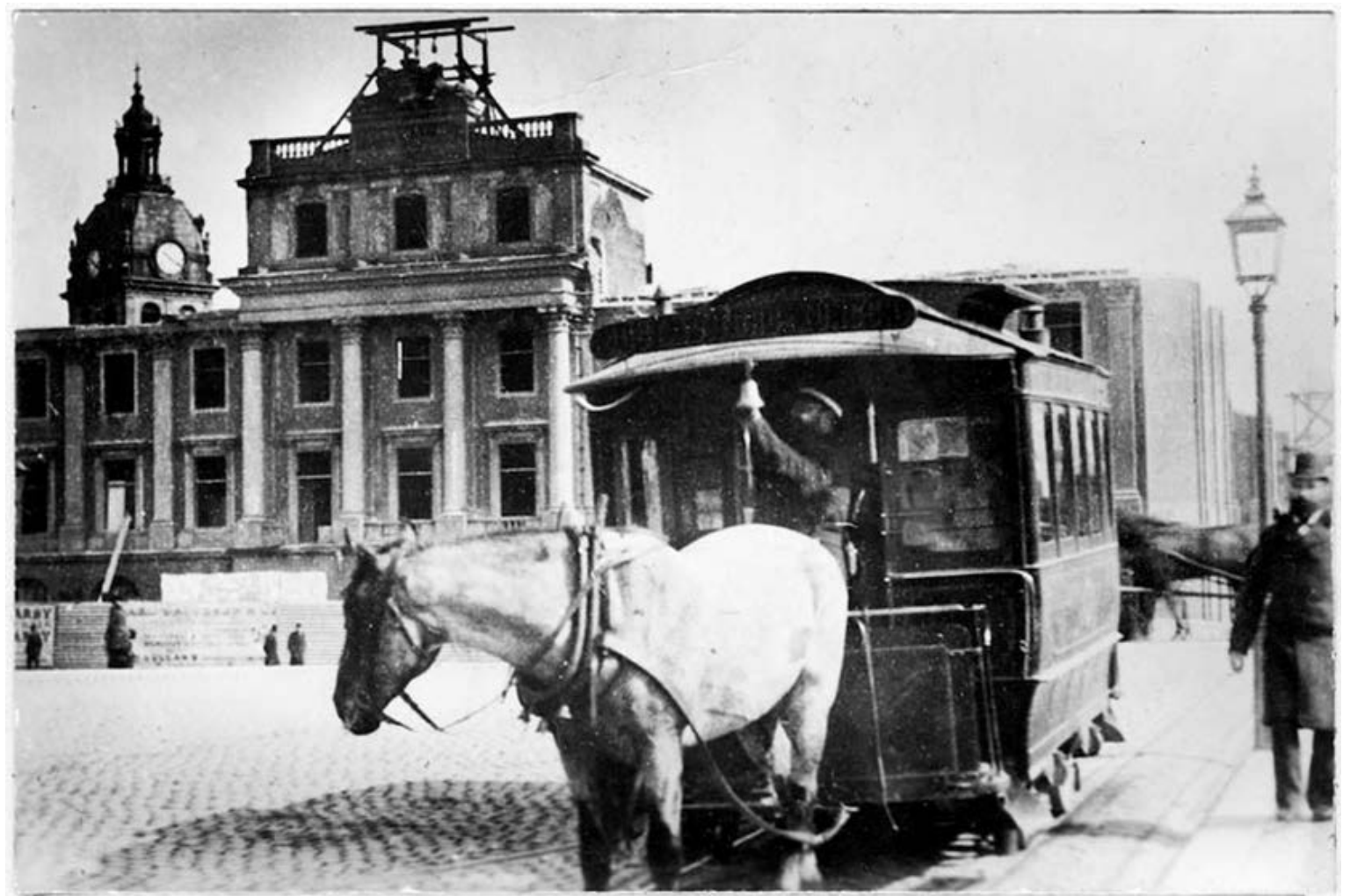

Bild 4. Operahusets rivning, fotografi av Odelberg från 1892, Stockholms Spårvägsmuseum, tillgängligt på www.stockholmskallan.stockholm.se.

I februari 1892 påbörjades rivningen av operahuset. En privat arrendator bedrev verksamhet på en annan teater tills det nya operahuset kunde tas i bruk på samma plats 1897, nu organiserat som ett aktiebolag. Och det är samma operahus som används än idag.

Det tog alltså nästan 100 år för Operan i Stockholm att gå från att vara en kunglig hovopera till att bli en statlig kulturinstitution. Under tiden som politiska diskussioner om organisation och ekonomi pågick gavs hela tiden föreställningar som lockade många besökare. Men man kan nog knappast säga att Operan under 1800-talet blev "kultur för alla” även om den efterhand blev intressant för allt fler. 